CLINICAL STUDY

\title{
Polymorphisms of TCF7L2 gene in South Brazilian women with polycystic ovary syndrome: a cross-sectional study
}

\author{
Ramon Bossardi Ramos ${ }^{1}$, Denusa Wiltgen ${ }^{1}$ and Poli Mara Spritzer ${ }^{1,2}$ \\ ${ }^{1}$ Gynecological Endocrinology Unit, Division of Endocrinology, Hospital de Clínicas de Porto Alegre, Rua Ramiro Barcelos, 2350, 90035 -003 Porto \\ Alegre, RS, Brazil and ${ }^{2}$ Laboratory of Molecular Endocrinology, Department of Physiology, Universidade Federal do Rio Grande do Sul, Porto Alegre, \\ RS, Brazil \\ (Correspondence should be addressed to P M Spritzer at Gynecological Endocrinology Unit, Division of Endocrinology, Hospital de Clínicas de Porto Alegre; \\ Email: spritzer@ufrgs.br)
}

\begin{abstract}
Objective: To assess whether TCF7L2 single nucleotide polymorphisms rs7903146 C/T and rs11196236 C/T are associated with polycystic ovary syndrome (PCOS) in South Brazilian women. Design: Cross-sectional study.

Methods: Two hundred PCOS patients and 102 non-hirsute, ovulatory controls were genotyped by real-time PCR. Haplotypes were constructed from the combination of both polymorphisms. Frequencies were inferred using the PHASE 2.1.1 software.

Results and conclusions: The distribution of rs7903146 (PCOS, $54.4 \%$ CC; $28.5 \%$ CT; $17.1 \%$ TT; controls, 51.0\% CC; 37.0\% CT; 12.0\% TT) and rs11196236 (PCOS, 4.3\% CC; 33.5\% CT; 62.2\% TT; controls, $3.2 \%$ CC; $35.5 \%$ CT; $61.3 \%$ TT) was similar between the groups. rs7903146 and rs 11196236 were not in linkage disequilibrium $\left(\left|D^{\prime}\right|=0.34 ; r^{2}=0.07\right)$. PCOS participants were younger, with higher age-adjusted BMI, waist circumference, blood pressure, triglycerides, insulin, homeostasis model assessment index to estimate insulin resistance and total testosterone, and lower HDL-C and sex hormone binding globulin vs controls. In PCOS, no differences between genotypes and haplotypes were found for clinical and metabolic variables. However, for each T (rs7903146) and T (rs11196236) allele added to the haplotypes, a variation of $5.87 \mathrm{~cm}$ in waist $(P$ trend $=0.01), 10.7 \mathrm{mg} / \mathrm{dl}$ in total cholesterol $(P$ trend $=0.03)$, and $10.3 \mathrm{mg} / \mathrm{dl}$ in LDL-C $(P$ trend $=0.01)$ was recorded. TCF7L2 variants are probably not implicated in PCOS development in South Brazilian women.
\end{abstract}

European Journal of Endocrinology 169 569-576

\section{Introduction}

Polycystic ovary syndrome (PCOS) is a complex endocrine disease characterized by hyperandrogenism and chronic anovulation. It is associated with metabolic disturbances such as central obesity, insulin resistance, dyslipidemia, and increased risk of diabetes and hypertension $(1,2,3,4,5,6)$.

Current evidence indicates that PCOS is a multifactorial polygenic disorder, whose pathogenesis and clinical presentation are influenced by both genetic susceptibility and environmental exposure $(5,7)$. To date, a number of genes have been reported to be associated with PCOS. Most of them are presumed to be relevant to the pathogenesis of PCOS, such as the genes encoding steroid biosynthesis enzymes and androgen and insulin receptors. However, a variant contributing substantially to the development of PCOS has not been identified $(8,9)$.

Recently, common variants of the transcription factor 7-like 2 (TCF7L2) gene on chromosome $10 \mathrm{q} 25.2$ have been found to contribute to the risk of type 2 diabetes (T2DM) in various ethnic groups $(10,11,12,13)$. Association studies on the single nucleotide polymorphisms (SNPs) of the TCF7L2 gene in PCOS women have produced controversial data, with some studies showing association between SNPs rs7903146 and rs11196236 with obesity-related traits (14) and peripheral insulin resistance (15) and others reporting no such association $(16,17)$.

Therefore, the aim of our study was to assess whether TCF7L2 SNPs rs7903146 C/T and rs11196236 C/T or their haplotypes are associated with PCOS and to determine a possible impact of these polymorphisms on anthropometric and metabolic variables in PCOS women from Southern Brazil.

\section{Subjects and methods}

\section{Patients}

We studied 302 women, including 200 PCOS patients and 102 non-hirsute women with regular ovulatory 
cycles (luteal phase progesterone $>3.8 \mathrm{ng} / \mathrm{ml}$ ). All participants were of reproductive age, consulting at a university hospital in Brazil or recruited by advertisement in local media between 2009 and 2012. PCOS was diagnosed according to Rotterdam criteria, in the presence of two of three signs: i) oligomenorrhea and/or chronic anovulation $(\leq 9$ cycles/year and/or luteal phase progesterone $<3.8 \mathrm{ng} / \mathrm{ml})$; ii) clinical and/or biochemical hyperandrogenism; and iii) polycystic ovaries. Diagnosis of PCOS also relied on exclusion of other hyperandrogenic disorders (18). None of the PCOS or control participants had received any drugs known to interfere with hormonal levels (such as OC pills, antiandrogens, metformin, fibrates, and statins) for at least 3 months before the study. Exclusion criteria were pregnancy and hepatic or renal diseases. Approval for this study was obtained from the institutional review board and the local ethics committee, functioning according to the 3rd edition of the Guidelines on the Practice of Ethical Committees in Medical Research issued by the Royal College of Physicians of London, and written informed consent was obtained from every subject.

\section{Study protocol}

Participants were evaluated according to a standard protocol, as previously reported $(19,20)$. Anthropometric measures included weight, height, and waist circumference (WC) (waist measured at the mid point between the lower rib margin and the iliac crest) (21). BMI was then calculated (current weight in kilograms divided by square of height in meters). Blood pressure was measured after a 10-min rest, in the sitting position, with feet on the floor and the arm supported at heart level. Two measurements were performed $10 \mathrm{~min}$ apart using automatic blood pressure monitor HEM-742INT OMRON (Rio de Janeiro, Brazil) with correct cuff size for the arm diameter. Hypertension was defined as systolic blood pressure (SBP) $\geq 140 \mathrm{mmHg}$, diastolic blood pressure (DBP) $\geq 90 \mathrm{mmHg}$, or current use of antihypertensive drugs (22). Hormonal and metabolic assessments were made between days 2 and 10 of the menstrual cycle, or on any day if the patient was amenorrheic. All samples were obtained between 0800 and $1000 \mathrm{~h}$. Blood samples were drawn after a 12-h overnight fast for determination of plasma cholesterol, HDL-C, triglycerides, total testosterone (TT), and sex hormone binding globulin (SHBG). Glucose was measured before and $2 \mathrm{~h}$ after the ingestion of a 75-g oral glucose load.

\section{Assays}

Total cholesterol, HDL-C, triglycerides, and glucose were determined by enzymatic colorimetric methods (Bayer 1650 Advia System). LDL-C was estimated indirectly with the Friedewald formula (23). The lipid accumulation product (LAP) index was calculated using the formula (waist $(\mathrm{cm})-58) \times$ triglyceride concentration $(\mathrm{mmol} / \mathrm{l})(24)$. Homeostasis model assessment index to estimate insulin resistance (HOMA-IR) was calculated by multiplying insulin $(\mathrm{mIU} / \mathrm{ml})$ by glucose $(\mathrm{mmol} / \mathrm{l})$ and dividing this product by 22.5 (25). Frequency of the metabolic syndrome was defined in accordance with the Joint Scientific Statement (26).

TT levels were measured by chemiluminescence (Siemens Advia Centaur XP, Mannheim, Germany), with a sensitivity of $0.10 \mathrm{ng} / \mathrm{ml}$ and intra-assay and interassay coefficient of variation (CV) of 3.3 and $7.5 \%$ respectively. SHBG was measured by chemiluminescence (Immulite 2000 Siemens), with a sensitivity of $0.02 \mathrm{nmol} / \mathrm{l}$ and intra-assay and interassay CV of 5.3 and $6.6 \%$ respectively. Plasma insulin levels were measured by electrochemiluminescence (Siemens Advia Centaur XP), with a sensitivity of $0.50 \mathrm{U} / \mathrm{ml}$ and intra-assay and interassay $\mathrm{CV}$ of 2.8 and $2.1 \%$ respectively.

\section{Genotyping}

In addition to serum samples, whole blood samples were collected from all participants. Genomic DNA was extracted from peripheral leukocytes using the technique described by Miller et al. (27). DNA samples were diluted to $2 \mathrm{ng} / \mathrm{ml}$ and genotyped for SNP 7903146 $\mathrm{C}>\mathrm{T}$ and $\mathrm{rs} 11196236 \mathrm{C}>\mathrm{T}$ of the TCF7L2 gene by real-time PCR (7500 Fast; Applied Biosystems), with allelic discrimination assays (Taqman MGB Probes) following the manufacturer's instructions (Applied Biosystems). Reaction conditions for SNP rs7903146 were $10 \mathrm{~min}$ at $95^{\circ} \mathrm{C}$ after 60 cycles of denaturation at $95{ }^{\circ} \mathrm{C}(15 \mathrm{~s})$ and annealing at $62^{\circ} \mathrm{C}(1 \mathrm{~min})$. Reaction conditions for rs 11196236 were $10 \mathrm{~min}$ at $95^{\circ} \mathrm{C}$ after 50 denaturation cycles at $95^{\circ} \mathrm{C}(15 \mathrm{~s})$ and annealing at $62{ }^{\circ} \mathrm{C}(1 \mathrm{~min})$. Endpoint fluorescent readings were performed by 7500 Fast System Sequence Detection Software version 1.4 . In this sample, $10 \%$ were made in duplicate.

After frequency analyses, a dominant model was assumed and PCOS carriers of allele $\mathrm{C}$ were analyzed together in both polymorphisms. Therefore, Lewontin's $D^{\prime}\left(\left|D^{\prime}\right|\right) r^{2}$ was calculated for each pair of genetic markers for estimating linkage disequilibrium $(28,29)$. Haplotypes were constructed from the combination of the two TCF7L2 polymorphisms (rs7903146 and rs11196236), and their frequencies were inferred using the PHASE 2.1.1 software (30). The first letter in each haplotype refers to the rs7903146 polymorphism and the second to the rs11196236 polymorphism.

\section{Statistical analysis}

Sample size estimation was based on a pilot study with PCOS participants, in which we found a non-significant 
Table 1 Clinical, hormonal, and metabolic features of patients with PCOS. Values are expressed as mean \pm S.D. or median (25-75 interquartile range). Total testosterone reference range (female): $0.2-0.8 \mathrm{ng} / \mathrm{ml}$.

\begin{tabular}{lccc}
\hline Variable & $\begin{array}{c}\text { PCOS } \\
(n=200)\end{array}$ & $\begin{array}{c}\text { Controls } \\
(n=102)\end{array}$ & $\boldsymbol{P}$ \\
\hline Age & $22.8 \pm 6.6$ & $25.2 \pm 7.6$ & 0.005 \\
BMI $\left(\mathrm{kg} / \mathrm{m}^{2}\right)$ & $30.2 \pm 7.1$ & $27.0 \pm 6.0$ & 0.001 \\
SBP $(\mathrm{mmHg})$ & $121.8 \pm 16.2$ & $109.6 \pm 12.8$ & 0.001 \\
DBP $(\mathrm{mmHg})$ & $78.3 \pm 11.6$ & $70.8 \pm 9.3$ & 0.001 \\
Waist circumference (cm) & $90.3 \pm 16.4$ & $78.1 \pm 11.5$ & 0.001 \\
Triglycerides $(\mathrm{mg} / \mathrm{dll})$ & $91(63-131)$ & $66(50-99)$ & 0.001 \\
Total cholesterol (mg/dl) & $175 \pm 38$ & $170 \pm 30$ & 0.23 \\
HDL-C $(\mathrm{mg} / \mathrm{dl})$ & $48 \pm 10$ & $52 \pm 12$ & 0.003 \\
LDL-C $(\mathrm{mg} / \mathrm{dll})$ & $105 \pm 32$ & $101 \pm 26$ & 0.35 \\
Fasting glucose $(\mathrm{mg} / \mathrm{dl})$ & $89 \pm 16$ & $88 \pm 7$ & 0.46 \\
Glucose at $120 \mathrm{~min}(\mathrm{mg} / \mathrm{dl})$ & $113 \pm 40$ & $95 \pm 20$ & 0.001 \\
Fasting insulin $(\mu \mathrm{Ul} / \mathrm{ml})$ & $17.6(9.9-28.1)$ & $11.0(7.3-15.4)$ & 0.001 \\
HOMA-IR & $3.6(1.9-6.5)$ & $2.1(1.3-3.1)$ & 0.001 \\
LAP & $30.3(14.2-60.5)$ & $14.2(6.9-24.4)$ & 0.001 \\
SHBG (mmol/l) & $24.0(15.0-37.2)$ & $39.3(29.3-56.5)$ & 0.001 \\
Total testosterone $(\mathrm{ng} / \mathrm{ml})$ & $0.91 \pm 0.4$ & $0.53 \pm 0.1$ & 0.001 \\
\hline
\end{tabular}

SBP, systolic blood pressure; DBP, diastolic blood pressure; HOMA-IR homeostatic model assessment of insulin resistance; LAP, lipid accumulation product index.

association between rs7903146 variants of the TCF7L2 gene and WC. Therefore, considering a difference of $6 \mathrm{~cm}$ in WC between the genotypes, an $\alpha$ of $5 \%$ and a $\beta$ of $80 \%$, the sample size was estimated as 264 PCOS participants. A subsequent interim analysis showed that a difference of $6 \mathrm{~cm}$ in WC was actually obtained with the sample of 200 PCOS enrolled in the study.

Results are presented as mean \pm s.D. for variables with normal distribution or as median and interquartile range for variables with non-Gaussian distribution. Non-Gaussian variables were log-transformed for statistical analysis with independent Student's $t$-test and one-way ANOVA and reported back-transformed in their original units. To account for multiple comparisons, Bonferroni correction procedure was applied and $P$ values $\leq 0.002$ were considered significant. A test for linear trend was used to test co-dominant effects of genotypes on dependent variables. All analyses were performed using the Statistical Package for the Social Sciences (SPSS version 20).

\section{Results}

Participants were mostly Caucasian (94.2\%), with the remaining participants having mixed (African and European) ancestry. Mean age was 23.7 \pm 7.1 years. In the PCOS group, $25.5 \%$ patients had metabolic syndrome and $25.3 \%$ had hypertension. In the control group, $2.3 \%$ participants had metabolic syndrome and $6.9 \%$ had hypertension.

Table 1 summarizes the clinical, metabolic, and hormonal profile of PCOS and control participants. Total cholesterol, LDL-C, and fasting glucose were similar between the groups. Women with PCOS were significantly younger than controls. As expected, women with PCOS also had significantly higher BMI, SBP, DBP, WC, serum triglycerides, glucose at $120 \mathrm{~min}$, fasting insulin, HOMA-IR, LAP, and TT and lower SHBG in comparison with the control group. These results remained significant even when adjusted for age.

For the 200 women in the PCOS group, the frequencies of genotypes for polymorphism rs7903146 were as follows: $54.4 \%$ for CC genotype, $28.5 \%$ for heterozygous CT, and $17.1 \%$ for TT genotype. These frequencies did not differ from those recorded for the control group: $51.0 \%$ for CC genotype, $37.0 \%$ for heterozygous CT, and $12.0 \%$ for homozygous TT genotype (Table 2). Of the attempted genotypes, 96.5\% were successful for this SNP. Genotypic distributions of SNP rs11196236 in women with PCOS were $4.3 \%$ for CC genotype, $33.5 \%$ for heterozygous CT, and $62.2 \%$ for homozygous TT genotype. Similar frequencies were observed in controls: $3.2 \%$ for CC, $35.5 \%$ for heterozygous CT, and $61.3 \%$ for homozygous TT genotype (Table 2). Of the attempted genotypes, $93.0 \%$ were successful for this SNP. The genotype distributions for both SNPs were in Hardy-Weinberg equilibrium in controls.

The rs7903146 polymorphism was not in linkage disequilibrium with the rs11196236 polymorphism $\left(\left|D^{\prime}\right|=0.34 ; r^{2}=0.07\right)$. Ten haplotypes were inferred in this sample (Ht1: CCCC, Ht2: CCCT, Ht3: CCTC, Ht4: CTCT, Ht5: CTTC, Ht6: CTTT, Ht7: TCTC, Ht8: TCTT, HT9: TTCT, and HT10: TTTT). Haplotype frequencies were $18.5 \%$ for $\mathrm{Ht} 1 / \mathrm{Ht} 2 / \mathrm{Ht} 3,69.5 \%$ for $\mathrm{Ht} 4 / \mathrm{Ht} 5 /$ $\mathrm{Ht} 6 / \mathrm{Ht} 7 / \mathrm{Ht} 8$, and $12.0 \%$ for $\mathrm{Ht} 9 / \mathrm{Ht} 10$.

Subsequent analyses were made specifically with the PCOS group. Table 3 shows clinical and metabolic variables according to SNP rs7903146 genotypes. There were no differences between genotypes for any of the studied variables.

Table 4 presents clinical and metabolic variables according to SNP rs11196236 genotypes in PCOS. No statistical differences were observed among the different genotypes for the studied variables.

Table 2 Genotype distribution of polymorphisms rs7903146 and rs 11196236 in the TCF7L2 gene in PCOS women. Data expressed as $\%\left(\chi^{2}\right.$ test $)$.

\begin{tabular}{lccc}
\hline & \multicolumn{2}{c}{ Frequency $(\%)$} & \\
\cline { 2 - 3 } & PCOS & Controls & $P$ \\
\hline Rs7903146 & & & \\
CC & 54.4 & 51.0 & \\
CT & 28.5 & 37.0 & 0.25 \\
TT & 17.1 & 12.0 & \\
Rs11196236 & & & \\
CC & 4.3 & 3.2 & \\
CT & 33.5 & 35.5 & 0.97 \\
TT & 62.2 & 61.3 & \\
\hline
\end{tabular}


Table 3 Clinical and metabolic characteristics of PCOS women according to genotypes of polymorphism rs7903146 in the TCF7L2 gene. Data are presented as mean \pm s.D. or median (25-75 interquartile range).

\begin{tabular}{|c|c|c|c|}
\hline & \multicolumn{2}{|c|}{ Pcos } & \multirow[b]{2}{*}{$P$} \\
\hline & $\mathrm{CC} / \mathrm{CT}$ & TT & \\
\hline BMI $\left(\mathrm{kg} / \mathrm{m}^{2}\right)$ & $29.8 \pm 7.1$ & $32.8 \pm 7.2$ & 0.030 \\
\hline $\mathrm{SBP}(\mathrm{mmHg})$ & $121.8 \pm 17.4$ & $123.8 \pm 10.5$ & 0.51 \\
\hline $\mathrm{DBP}(\mathrm{mmHg})$ & $77.9 \pm 12.1$ & $81.3 \pm 9.2$ & 0.13 \\
\hline Waist circumference $(\mathrm{cm})$ & $89.3 \pm 16.2$ & $96.1 \pm 16.7$ & 0.034 \\
\hline Triglycerides (mg/dl) & $90(62-131)$ & $89(63-132)$ & 0.76 \\
\hline Total cholesterol (mg/dl) & $175 \pm 40$ & $172 \pm 33$ & 0.65 \\
\hline HDL-C (mg/dl) & $49 \pm 11$ & $46 \pm 10$ & 0.30 \\
\hline LDL-C (mg/dl) & $104 \pm 33$ & $105 \pm 29$ & 0.96 \\
\hline Fasting glucose (mg/dl) & $89 \pm 15$ & $90 \pm 18$ & 0.70 \\
\hline Glucose at $120 \mathrm{~min}(\mathrm{mg} / \mathrm{dl})$ & $113 \pm 40$ & $115 \pm 38$ & 0.80 \\
\hline Fasting insulin $(\mu \mathrm{Ul} / \mathrm{ml})$ & $17.7(9.8-28.5)$ & $16.4(11.8-25.6)$ & 0.94 \\
\hline HOMA-IR & $3.7(1.9-6.6)$ & $3.5(1.9-5.8)$ & 0.98 \\
\hline LAP & $27.6(13.1-60.3)$ & $36.9(21.2-74.0)$ & 0.09 \\
\hline $\mathrm{SHBG}(\mathrm{mmol} / \mathrm{l})$ & $23.3(14.8-38.3)$ & $29.0(17.4-41.4)$ & 0.17 \\
\hline
\end{tabular}

SBP, systolic blood pressure; DBP, diastolic blood pressure; HOMA-IR homeostatic model assessment of insulin resistance; LAP, lipid accumulation product index.

Table 5 shows clinical and metabolic variables according to haplotypes in PCOS. Individuals with the Ht9/Ht10 haplotype had a non-significant higher WC $(P=0.02)$ and LDL-C $(P=0.03)$ compared with Ht1/Ht2/Ht3. In addition, for each T (rs7903146) and $\mathrm{T}$ (rs11196236) allele added to the haplotypes, a variation of $5.87 \mathrm{~cm}$ in waist $(P$ trend $=0.01)$, $10.7 \mathrm{mg} / \mathrm{dl}$ in total cholesterol $(P$ trend $=0.03)$, and $10.3 \mathrm{mg} / \mathrm{dl}$ in LDL-C $(P$ trend $=0.01)$ was recorded (Fig. 1).

\section{Discussion}

In this study, SNPs rs7903146 and rs11196236 of the TCF7L2 gene were not associated with the occurrence of PCOS in women from South Brazil. Previous genetic association studies with PCOS patients, although not entirely conclusive, have shown similar results. Barber et al. (31), studying 369 women with PCOS and 2574 controls of UK British or Irish origin, and 540 PCOS and 1083 controls from the Northern Finland Birth Cohort of 1966 found no association of polymorphism rs7903146 with PCOS. That was also the case with another large study analyzing 624 PCOS and 553 control women of European ancestry, which did not find an association between rs7903146 of TCF7L2 and PCOS. However, the latter study reported that variation in a specific region of the gene, where SNP rs11196236 is located, was associated with reproductive and metabolic quantitative traits in PCOS (32). Studies focusing on SNP rs7903146 in Chinese (33) and Korean women (34) were also unable to detect an association with PCOS. The genotype distribution of the TCF7L2 variants found in our PCOS women and controls agree with these earlier findings $(14,31)$.

Interestingly, we found that the haplotypes Ht9/Ht10 were weakly associated with obesity-related traits and LDL-C. While very few studies are available in PCOS populations, studies with diabetic individuals have shown analogous associations of TCF7L2 and obesityrelated traits $(14,35,36)$. In North India, Sanghera et al. (37) observed increased cholesterol and LDL-C levels in risk allele carriers of SNP rs7903146; SNP rs7903146 was associated with high triglyceride levels in Mexican and Finnish populations $(38,39)$. Moreover, a meta-analysis indicated an association between the T allele of rs7903146 and the metabolic syndrome (40). By contrast, other studies with diabetic populations did not find an influence on body weight $(37,41,42)$. Our sample size of 200 PCOS may have been a limiting factor for these multiple analyses regarding associations between genotype and metabolic variables.

It is well established that common polymorphisms of the TCF 7L2 gene are associated with T2DM $(10,41$, 43, 44). Grant et al. (10) have shown that microsatellite DG10S478 of the TCF 7L2 gene increases the risk of T2D by $\sim 1.45$ in heterozygotes and 2.41 in homozygotes. In that study, DG10S478 was in strong linkage disequilibrium with rs7903146. The TT genotype of rs7903146 also predicted the risk of diabetes in the Diabetes Prevention Program (DPP) (36) and the Finnish Diabetes Prevention Study (45).

In this sense, studies demonstrate that variation in the TCF7L2 gene is associated with defects in insulin secretion $(46,47,48)$. Greater proinsulin/insulin ratio has consistently been observed among rs7903146 T allele carriers; contrarily, associations with proinsulin level have been less consistent $(42,47,49)$. In PCOS women with abnormal glucose tolerance,

Table 4 Clinical and metabolic characteristics of PCOS women according to genotypes of polymorphism rs11196236 in the TCF7L2 gene. Data are presented as mean \pm S.D. or median and interquartile range (25th-75th percentile).

\begin{tabular}{lccc}
\hline & \multicolumn{2}{c}{ PCOS } \\
\cline { 2 - 3 } & CC/CT $(70)$ & TT $(115)$ & $P$ \\
\hline BMI $\left(\mathrm{kg} / \mathrm{m}^{2}\right)$ & $29.2 \pm 6.8$ & $30.7 \pm 7.4$ & 0.16 \\
SBP $(\mathrm{mmHg})$ & $119.0 \pm 12.4$ & $123.4 \pm 18.2$ & 0.08 \\
DBP (mmHg) & $76.9 \pm 11.2$ & $78.6 \pm 11.7$ & 0.35 \\
Waist circumference (cm) & $86.8 \pm 14.4$ & $91.7 \pm 17.3$ & 0.05 \\
Triglycerides (mg/dl) & $88(60-125)$ & $93(65-139)$ & 0.44 \\
Total cholesterol $(\mathrm{mg} / \mathrm{dl})$ & $165 \pm 34$ & $180 \pm 40$ & 0.01 \\
HDL-C (mg/dl) & $48 \pm 10$ & $48 \pm 10$ & 0.89 \\
LDL-C (mg/dl) & $96 \pm 27$ & $109 \pm 34$ & 0.004 \\
Fasting glucose (mg/dl) & $90 \pm 20$ & $89 \pm 13$ & 0.59 \\
Glucose at 120 min (mg/dl) & $114 \pm 51$ & $113 \pm 33$ & 0.86 \\
Fasting insulin ( $\mu$ Ul/ml) & $18.2(9.8-26.3)$ & $16.3(9.5-28.8)$ & 0.99 \\
HOMA-IR & $3.5(1.9-6.2)$ & $3.6(2.0-6.7)$ & 0.94 \\
LAP & $27.6(12.9-49.6)$ & $34.4(14.4-68.0)$ & 0.25 \\
SHBG (mmol/l) & $25.3(15.2-38.8)$ & $24.0(16.0-36.5)$ & 0.99 \\
\hline
\end{tabular}

SBP, systolic blood pressure; DBP, diastolic blood pressure; HOMA-IR, homeostatic model assessment of insulin resistance; LAP, lipid accumulation product. 
Table 5 Clinical and metabolic characteristics of PCOS women according to haplotype of TCF7L2 gene. Data are presented as mean \pm S.D. or median (25-75 interquartile range).

\begin{tabular}{|c|c|c|c|c|}
\hline & \multicolumn{3}{|c|}{ Pcos } & \multirow[b]{2}{*}{$\boldsymbol{P}$} \\
\hline & $\mathrm{Ht} 1 / \mathrm{Ht} 2 / \mathrm{Ht} 3$ & $\begin{array}{c}\mathrm{Ht} 4 / \mathrm{Ht} 5 / \mathrm{Ht} 6 / \\
\mathrm{Ht} 7 / \mathrm{Ht} 8\end{array}$ & $\mathrm{Ht} / \mathrm{Ht} 10$ & \\
\hline BMI $\left(\mathrm{kg} / \mathrm{m}^{2}\right)$ & $28.7 \pm 6.7$ & $30.2 \pm 7.3$ & $32.6 \pm 5.8$ & 0.11 \\
\hline $\mathrm{SBP}(\mathrm{mmHg})$ & $117 \pm 14$ & $122 \pm 17$ & $122.3 \pm 12.1$ & 0.26 \\
\hline $\mathrm{DBP}(\mathrm{mmHg})$ & $76 \pm 13$ & $78 \pm 11$ & $79 \pm 10$ & 0.48 \\
\hline $\begin{array}{l}\text { Waist circumference } \\
(\mathrm{cm})\end{array}$ & $85.9 \pm 15.4$ & $90.0 \pm 16.2$ & $98.3 \pm 16.8$ & 0.02 \\
\hline Triglycerides (mg/dl) & $89(54-125)$ & $91(65-137)$ & $93(63-147)$ & 0.60 \\
\hline $\begin{array}{l}\text { Total cholesterol } \\
\text { (mg/dl) }\end{array}$ & $162 \pm 31$ & $177 \pm 40$ & $181 \pm 34$ & 0.06 \\
\hline HDL-C (mg/dl) & $47 \pm 11$ & $49.2 \pm 10$ & $46.7 \pm 10$ & 0.47 \\
\hline LDL-C (mg/dl) & $92 \pm 26$ & $107 \pm 33$ & $112 \pm 30$ & 0.03 \\
\hline $\begin{array}{l}\text { Fasting glucose } \\
\text { (mg/dl) }\end{array}$ & $88 \pm 17$ & $89.5 \pm 14$ & $90.3 \pm 20$ & 0.86 \\
\hline $\begin{array}{l}\text { Glucose at } 120 \mathrm{~min} \\
(\mathrm{mg} / \mathrm{dl})\end{array}$ & $109 \pm 49$ & $114 \pm 36$ & $116 \pm 44$ & 0.81 \\
\hline $\begin{array}{l}\text { Fasting insulin } \\
(\mu \mathrm{Ul} / \mathrm{ml})\end{array}$ & $18.5(10.0-30.6)$ & $16.9(10.5-28.1)$ & $16.8(12.7-33)$ & 0.29 \\
\hline HOMA-IR & $3.4(2.0-6.4)$ & $3.6(2.3-6.8)$ & $3.6(2.6-7.7)$ & \\
\hline LAP & $22.4(9.5-55.1)$ & $30.0(14.3-62.0)$ & $40.1(23.9-82)$ & 0.13 \\
\hline SHBG (mmol/l) & $24.0(12.4-38.8)$ & $23.2(16.0-35.6)$ & $28.8(17.9-36)$ & 0.45 \\
\hline
\end{tabular}

SBP, systolic blood pressure; DBP, diastolic blood pressure; HOMA-IR homeostatic model assessment of insulin resistance; LAP, lipid accumulation product index.

TCF7L2 polymorphisms were associated with defects in insulin secretion (32). Another study with a small sample of 31 PCOS women has found that SNP rs11196236 was associated with peripheral insulin (15). By contrast, similar to other studies with PCOS populations $(14,33,34)$, we did not find an association between insulin resistance and SNPs of the TCF7L2. It should be noted that differences in anthropometry, proportion of less severe phenotypes, and ethnicity among these PCOS populations could have, at least in part, masked the influence of TCF 7L2 SNPs on clinical expression of insulin resistance.

The mechanism linking the TCF7L2 gene with obesity traits and metabolic disturbances in diabetes has not been established. TCF7L2 encodes a transcriptional factor that mediates downstream Wnt signaling after binding with $\beta$-catenin. Some evidence indicates that TCF $7 L 2$ is significantly expressed in human target tissues for glucose homeostasis, including visceral and subcutaneous fat $(45,50,51)$, and that Wnt signaling could be a key regulator of adipogenesis through the $\beta$-catenin/TCF 7L2-dependent pathway (52). Thus, overexpression of Wnt signaling might block adipogenesis, whereas inhibition of TCF7L2 could stimulate adipogenesis, as observed in vitro (53). Such observations further support multiple effects of TCF $7 L 2$ on homeostasis through modulation of adipogenesis. However, it is unclear how these intronic variants of the TCF 7L2 gene may influence phenotypes. It is likely that these intronic variants act by affecting the expression of TCF $7 L 2$ rather than altering the structure of expressed protein (54). Wnt signaling could also affect insulin secretion (55). One hypothesis suggests that genetic variation in the TCF 7L2 gene might impair the expression of glucagon-like peptide 1 , possibly by Wnt/TCF7L2 pathways, which influences insulin secretion from the pancreatic $\beta$ cells $(10,56)$.

One limitation of this study was the relatively small sample size of 300 participants. However, the effect sizes
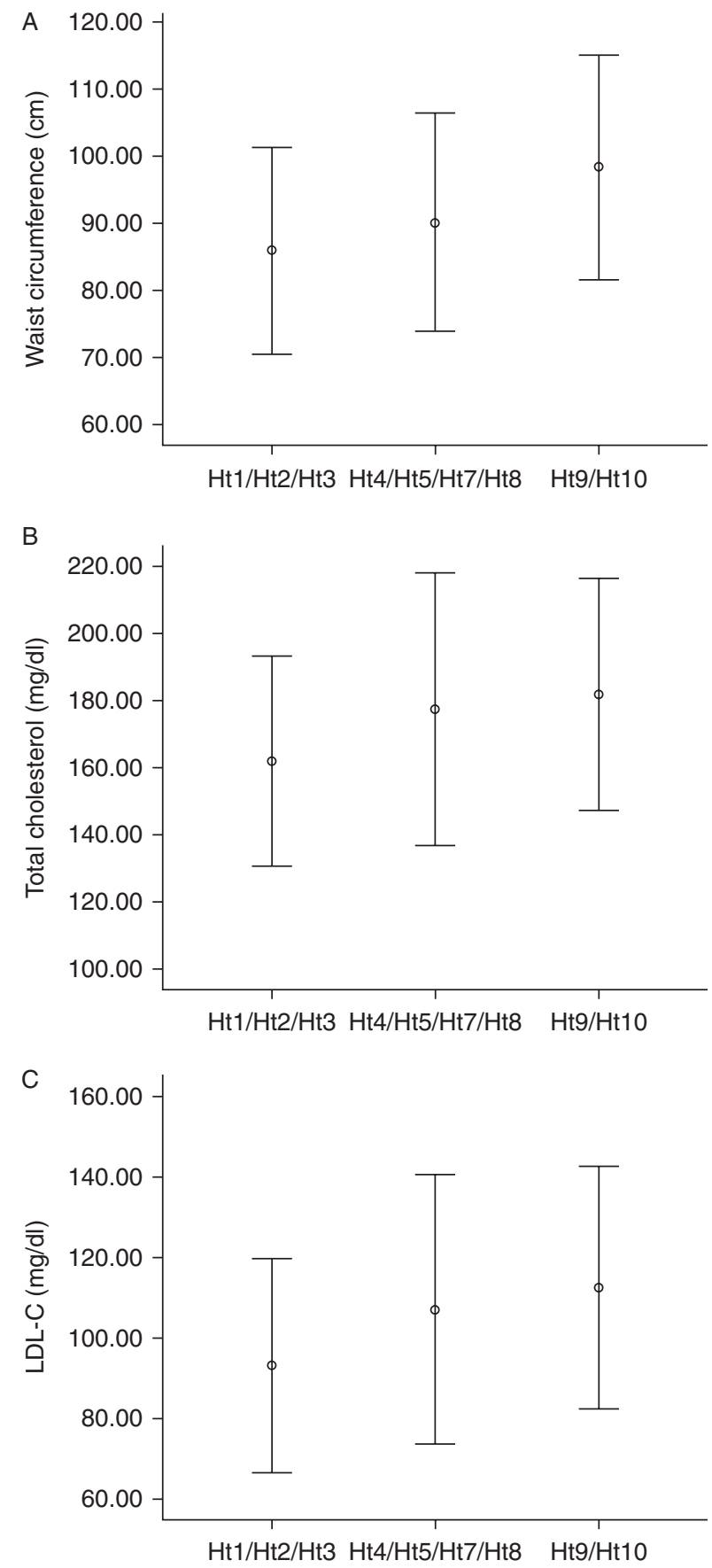

Figure 1 Association of haplotypes with waist circumference $(A)$, total cholesterol (B), and LDL-C (C). $P=0.02(\mathrm{~A}) ; P=0.06(\mathrm{~B})$; $P=0.03(\mathrm{C})$. 
observed in our sample are similar to those reported in other PCOS populations. Our data for haplotypes of the TCF7L2 gene suggest a weak association with some quantitative traits may be present in women with PCOS from Southern Brazil. However, further studies are needed with different populations to confirm these data, to elucidate the mechanisms through which TCF7L2 risk genotypes and haplotypes could influence obesityrelated traits and metabolic components and to establish further consequences of the interactions between genetic and environmental factors.

In conclusion, the present results suggest that variants of the TCF7L2 gene are not implicated in the development of PCOS in women from South Brazil.

\section{Declaration of interest}

The authors declare that there is no conflict of interest that could be perceived as prejudicing the impartiality of the research reported.

\section{Funding}

This work was supported by the Brazilian National Institute of Hormones and Women's Health/Conselho Nacional de Desenvolvimento Científico e Tecnológico (grant number: CNPq INCT 573747/2008-3), Brazil.

\section{References}

1 Berneis K, Rizzo M, Hersberger M, Rini GB, Di Fede G, Pepe I, Spinas GA \& Carmina E. Atherogenic forms of dyslipidaemia in women with polycystic ovary syndrome. International Journal of Clinical Practice 200963 56-62. (doi:10.1111/j.1742-1241. 2008.01897.x)

2 Wild RA, Carmina E, Diamanti-Kandarakis E, Dokras A, EscobarMorreale HF, Futterweit W, Lobo R, Norman RJ, Talbott E \& Dumesic DA. Assessment of cardiovascular risk and prevention of cardiovascular disease in women with the polycystic ovary syndrome: a consensus statement by the Androgen Excess and Polycystic Ovary Syndrome (AE-PCOS) Society. Journal of Clinical Endocrinology and Metabolism 201095 2038-2049. (doi:10.1210/jc.2009-2724)

3 Diamanti-Kandarakis E, Spritzer PM, Sir-Petermann T \& Motta AB. Insulin resistance and polycystic ovary syndrome through life. Current Pharmaceutical Design 201218 5569-5576. (doi:10.2174/ 138161212803307590)

4 Ehrmann DA. Polycystic ovary syndrome. New England Journal of Medicine 2005352 1223-1236. (doi:10.1056/NEJMra 041536)

5 Azziz R, Carmina E, Dewailly D, Diamanti-Kandarakis E, EscobarMorreale HF, Futterweit W, Janssen OE, Legro RS, Norman RJ, Taylor AE et al. The Androgen Excess and PCOS Society criteria for the polycystic ovary syndrome: the complete task force report. Fertility and Sterility 200991 456-488. (doi:10.1016/j.fertnstert. 2008.06.035)

6 Norman RJ, Dewailly D, Legro RS \& Hickey TE. Polycystic ovary syndrome. Lancet 2007 370 685-697. (doi:10.1016/S01406736(07)61345-2)

7 Jones MR, Chua AK, Mengesha EA, Taylor KD, Chen YD, Li X, Krauss RM, Rotter JI, Reproductive Medicine N, Legro RS et al. Metabolic and cardiovascular genes in polycystic ovary syndrome: a candidate-wide association study (CWAS). Steroids $2012 \mathbf{7 7}$ 317-322. (doi:10.1016/j.steroids.2011.12.005)

8 Rashidi B, Azizy L, Najmeddin F \& Azizi E. Prevalence of the insulin receptor substrate-1 (IRS-1) Gly972Arg and the insulin receptor substrate-2 (IRS-2) Gly1057Asp polymorphisms in PCOS patients and non-diabetic healthy women. Journal of Assisted Reproduction and Genetics 201229 195-201. (doi:10.1007/s10815-0119693-7)

9 Li Y, Liu F, Luo S, Hu H, Li XH \& Li SW. Polymorphism T $\rightarrow$ C of gene CYP17 promoter and polycystic ovary syndrome risk: a meta-analysis. Gene 2012495 16-22. (doi:10.1016/j.gene.2011. 12.048)

10 Grant SF, Thorleifsson G, Reynisdottir I, Benediktsson R, Manolescu A, Sainz J, Helgason A, Stefansson H, Emilsson V, Helgadottir A et al. Variant of transcription factor 7-like 2 (TCF7L2) gene confers risk of type 2 diabetes. Nature Genetics 200638 320-323. (doi:10.1038/ng1732)

11 Cauchi S, Vaxillaire M, Choquet H, Durand E, Duval A, Polak M \& Froguel P. No major contribution of TCF7L2 sequence variants to maturity onset of diabetes of the young (MODY) or neonatal diabetes mellitus in French white subjects. Diabetologia 200750 214-216. (doi:10.1007/s00125-006-0505-z)

12 Ereqat S, Nasereddin A, Cauchi S, Azmi K, Abdeen Z \& Amin R. Association of a common variant in TCF7L2 gene with type 2 diabetes mellitus in the Palestinian population. Acta Diabetologica $2010 \quad 47$ (Suppl 1) 195-198. (doi:10.1007/ s00592-009-0161-0)

13 Barra GB, Dutra LA, Watanabe SC, Costa PG, Cruz PS, Azevedo MF \& Amato AA. Association of the rs7903146 single nucleotide polymorphism at the transcription factor 7-like 2 (TCF7L2) locus with type 2 diabetes in Brazilian subjects. Arquivos Brasileiros de Endocrinologia e Metabologia 201256 479-484. (doi:10.1590/ S0004-27302012000800003)

14 Tan S, Scherag A, Janssen OE, Hahn S, Lahner H, Dietz T, Scherag S, Grallert H, Vogel CI, Kimmig R et al. Large effects on body mass index and insulin resistance of fat mass and obesity associated gene (FTO) variants in patients with polycystic ovary syndrome (PCOS). BMC Medical Genetics 20101112. (doi:10.1186/1471-2350-11-12)

15 Yalamanchi SK, Sam S, Cardenas MO, Holaday LW, Urbanek M \& Dunaif A. Association of fibrillin-3 and transcription factor-7-like 2 gene variants with metabolic phenotypes in PCOS. Obesity 2012 20 1273-1278. (doi:10.1038/oby.2011.400)

16 Vcelak J, Vejrazkova D, Vankova M, Lukasova P, Bradnova O, Halkova T, Bestak J, Andelova K, Kvasnickova H, Hoskovcova P et al. T2D risk haplotypes of the TCF7L2 gene in the Czech population sample: the association with free fatty acids composition. Physiological Research $201261229-240$.

17 Wang J, Hu F, Feng T, Zhao J, Yin L, Li L, Wang Y, Wang Q \& $\mathrm{Hu}$ D. Meta-analysis of associations between TCF7L2 polymorphisms and risk of type 2 diabetes mellitus in the Chinese population. BMC Medical Genetics 201314 8. (doi:10.1186/ 1471-2350-14-8)

18 Rotterdam ESHRE/ASRM-Sponsored PCOS Consensus Workshop Group. Revised 2003 consensus on diagnostic criteria and longterm health risks related to polycystic ovary syndrome. Fertility and Sterility 200481 19-25. (doi:10.1093/humrep/deh098)

19 Wiltgen D, Benedetto IG, Mastella LS \& Spritzer PM. Lipid accumulation product index: a reliable marker of cardiovascular risk in polycystic ovary syndrome. Human Reproduction 200924 1726-1731. (doi:10.1093/humrep/dep072)

20 Di Domenico K, Wiltgen D, Nickel FJ, Magalhaes JA, Moraes RS \& Spritzer PM. Cardiac autonomic modulation in polycystic ovary syndrome: does the phenotype matter? Fertility and Sterility 2013 99 286-292. (doi:10.1016/j.fertnstert.2012.08.049)

21 Toscani M, Migliavacca R, Sisson de Castro JA \& Spritzer PM. Estimation of truncal adiposity using waist circumference or the sum of trunk skinfolds: a pilot study for insulin resistance screening in hirsute patients with or without polycystic ovary syndrome. Metabolism: Clinical and Experimental $2007 \mathbf{5 6}$ 992-997. (doi:10.1016/j.metabol.2007.03.006)

22 Chobanian AV, Bakris GL, Black HR, Cushman WC, Green LA, Izzo JL Jr, Jones DW, Materson BJ, Oparil S, Wright JT Jr et al. Seventh report of the Joint National Committee on Prevention, 
Detection, Evaluation, and Treatment of High Blood Pressure. Hypertension $2003 \mathbf{4 2}$ 1206-1252. (doi:10.1161/01.HYP. 0000107251.49515.c2)

23 Friedewald WT, Levy RI \& Fredrickson DS. Estimation of the concentration of low-density lipoprotein cholesterol in plasma, without use of the preparative ultracentrifuge. Clinical Chemistry 197218 499-502.

24 Kahn HS. The "lipid accumulation product" performs better than the body mass index for recognizing cardiovascular risk: a population-based comparison. BMC Cardiovascular Disorders 20055 26. (doi:10.1186/1471-2261-5-26)

25 Katz A, Nambi SS, Mather K, Baron AD, Follmann DA, Sullivan G \& Quon MJ. Quantitative insulin sensitivity check index: a simple, accurate method for assessing insulin sensitivity in humans. Journal of Clinical Endocrinology and Metabolism 2000 85 2402-2410. (doi:10.1210/jc.85.7.2402)

26 Alberti KG, Eckel RH, Grundy SM, Zimmet PZ, Cleeman JI, Donato KA, Fruchart JC, James WP, Loria CM, Smith SC Jr et al. Harmonizing the metabolic syndrome: a joint interim statement of the International Diabetes Federation Task Force on Epidemiology and Prevention; National Heart, Lung, and Blood Institute; American Heart Association; World Heart Federation; International Atherosclerosis Society; and International Association for the Study of Obesity. Circulation $2009 \mathbf{1 2 0} 1640-1645$. (doi:10.1161/CIRCULATIONAHA.109.192644)

27 Miller SA, Dykes DD \& Polesky HF. A simple salting out procedure for extracting DNA from human nucleated cells. Nucleic Acids Research 198816 1215. (doi:10.1093/nar/16.3.1215)

28 Hedrick PW. Gametic disequilibrium measures: proceed with caution. Genetics 1987117 331-341.

29 Lewontin RC. On measures of gametic disequilibrium. Genetics $1988 \mathbf{1 2 0} 849-852$.

30 Stephens M, Smith NJ \& Donnelly P. A new statistical method for haplotype reconstruction from population data. American Journal of Human Genetics 200168 978-989. (doi:10.1086/ 319501)

31 Barber TM, Bennett AJ, Groves CJ, Sovio U, Ruokonen A, Martikainen H, Pouta A, Hartikainen AL, Elliott P, Wass JA et al. Disparate genetic influences on polycystic ovary syndrome (PCOS) and type 2 diabetes revealed by a lack of association between common variants within the TCF7L2 gene and PCOS. Diabetologia 200750 2318-2322. (doi:10.1007/s00125-007-0804-z)

32 Biyasheva A, Legro RS, Dunaif A \& Urbanek M. Evidence for association between polycystic ovary syndrome (PCOS) and TCF7L2 and glucose intolerance in women with PCOS and TCF 7L2. Journal of Clinical Endocrinology and Metabolism 200994 2617-2625. (doi:10.1210/jc.2008-1664)

33 Xu P, Che Y, Cao Y, Wu X, Sun H, Liang F, Sun J, Ke L, Yi L \& Wang Y. Polymorphisms of TCF7L2 and HHEX genes in Chinese women with polycystic ovary syndrome. Journal of Assisted Reproduction and Genetics $2010 \quad 27$ 23-28. (doi:10.1007/ s10815-009-9377-8)

34 Kim JJ, Choi YM, Cho YM, Hong MA, Chae SJ, Hwang KR, Hwang SS, Yoon SH \& Moon SY. Polycystic ovary syndrome is not associated with polymorphisms of the TCF7L2, CDKAL1, HHEX, KCNJ11, FTO and SLC30A8 genes. Clinical Endocrinology 201277 439-445. (doi:10.1111/j.1365-2265.2012.04389.x)

35 Cauchi S, Nead KT, Choquet H, Horber F, Potoczna N, Balkau B, Marre M, Charpentier G, Froguel P \& Meyre D. The genetic susceptibility to type 2 diabetes may be modulated by obesity status: implications for association studies. BMC Medical Genetics 20089 45. (doi:10.1186/1471-2350-9-45)

36 Florez JC, Jablonski KA, Bayley N, Pollin TI, de Bakker PI, Shuldiner AR, Knowler WC, Nathan DM \& Altshuler D. TCF7L2 polymorphisms and progression to diabetes in the Diabetes Prevention Program. New England Journal of Medicine 2006355 241-250. (doi:10.1056/NEJMoa062418)

37 Sanghera DK, Nath SK, Ortega L, Gambarelli M, Kim-Howard X, Singh JR, Ralhan SK, Wander GS, Mehra NK, Mulvihill JJ et al. TCF7L2 polymorphisms are associated with type 2 diabetes in
Khatri Sikhs from North India: genetic variation affects lipid levels. Annals of Human Genetics $2008 \mathbf{7 2}$ 499-509. (doi:10.1111/ j.1469-1809.2008.00443.x)

38 Huertas-Vazquez A, Plaisier C, Weissglas-Volkov D, Sinsheimer J, Canizales-Quinteros S, Cruz-Bautista I, Nikkola E, HerreraHernandez M, Davila-Cervantes A, Tusie-Luna T et al. TCF7L2 is associated with high serum triacylglycerol and differentially expressed in adipose tissue in families with familial combined hyperlipidaemia. Diabetologia $2008 \quad 51$ 62-69. (doi:10.1007/ s00125-007-0850-6)

39 Warodomwichit D, Arnett DK, Kabagambe EK, Tsai MY, Hixson JE, Straka RJ, Province M, An P, Lai CQ, Borecki I et al. Polyunsaturated fatty acids modulate the effect of TCF7L2 gene variants on postprandial lipemia. Journal of Nutrition 2009139 439-446. (doi:10.3945/jn.108.096461)

40 Povel CM, Boer JM, Reiling E \& Feskens EJ. Genetic variants and the metabolic syndrome: a systematic review. Obesity Reviews 2011 12 952-967. (doi:10.1111/j.1467-789X.2011.00907.x)

41 Saxena R, Gianniny L, Burtt NP, Lyssenko V, Giuducci C, Sjogren M, Florez JC, Almgren P, Isomaa B, Orho-Melander M et al. Common single nucleotide polymorphisms in TCF7L2 are reproducibly associated with type 2 diabetes and reduce the insulin response to glucose in nondiabetic individuals. Diabetes 200655 2890-2895. (doi:10.2337/db06-0381)

42 Loos RJ, Franks PW, Francis RW, Barroso I, Gribble FM, Savage DB, Ong KK, O’Rahilly S \& Wareham NJ. TCF7L2 polymorphisms modulate proinsulin levels and $\beta$-cell function in a British Europid population. Diabetes 200756 1943-1947. (doi:10.2337/db070055)

43 Scott LJ, Bonnycastle LL, Willer CJ, Sprau AG, Jackson AU, Narisu N, Duren WL, Chines PS, Stringham HM, Erdos MR et al. Association of transcription factor 7-like 2 (TCF7L2) variants with type 2 diabetes in a Finnish sample. Diabetes 200655 2649-2653. (doi:10.2337/db06-0341)

44 Helgason A, Palsson S, Thorleifsson G, Grant SF, Emilsson V, Gunnarsdottir S, Adeyemo A, Chen Y, Chen G, Reynisdottir I et al. Refining the impact of TCF7L2 gene variants on type 2 diabetes and adaptive evolution. Nature Genetics 200739 218-225. (doi:10.1038/ng1960)

45 Wang J, Kuusisto J, Vanttinen M, Kuulasmaa T, Lindstrom J, Tuomilehto J, Uusitupa M \& Laakso M. Variants of transcription factor 7-like 2 (TCF7L2) gene predict conversion to type 2 diabetes in the Finnish Diabetes Prevention Study and are associated with impaired glucose regulation and impaired insulin secretion. Diabetologia 200750 1192-1200. (doi:10.1007/s00125-0070656-6)

46 Lyssenko V, Lupi R, Marchetti P, Del Guerra S, Orho-Melander M, Almgren P, Sjogren M, Ling C, Eriksson KF, Lethagen AL et al. Mechanisms by which common variants in the TCF7L2 gene increase risk of type 2 diabetes. Journal of Clinical Investigation 2007117 2155-2163. (doi:10.1172/JCI30706)

47 Kirchhoff K, Machicao F, Haupt A, Schafer SA, Tschritter O, Staiger H, Stefan N, Haring HU \& Fritsche A. Polymorphisms in the TCF7L2, CDKAL1 and SLC30A8 genes are associated with impaired proinsulin conversion. Diabetologia 2008 51 597-601. (doi:10.1007/s00125-008-0926-y)

48 McCaffery JM, Jablonski KA, Franks PW, Dagogo-Jack S, Wing RR, Knowler WC, Delahanty L, Dabelea D, Hamman R, Shuldiner AR et al. TCF7L2 polymorphism, weight loss and proinsulin:insulin ratio in the diabetes prevention program. PLoS ONE 20116 e21518. (doi:10.1371/journal.pone.0021518)

49 Stolerman ES, Manning AK, McAteer JB, Fox CS, Dupuis J, Meigs JB \& Florez JC. TCF7L2 variants are associated with increased proinsulin/insulin ratios but not obesity traits in the Framingham Heart Study. Diabetologia 200952 614-620. (doi:10.1007/s00125-009-1266-2)

50 Cauchi S, Meyre D, Dina C, Choquet H, Samson C, Gallina S, Balkau B, Charpentier G, Pattou F, Stetsyuk V et al. Transcription factor TCF7L2 genetic study in the French population: expression 
in human $\beta$-cells and adipose tissue and strong association with type 2 diabetes. Diabetes 200655 2903-2908. (doi:10.2337/ db06-0474)

51 Elbein SC, Chu WS, Das SK, Yao-Borengasser A, Hasstedt SJ, Wang H, Rasouli N \& Kern PA. Transcription factor 7-like 2 polymorphisms and type 2 diabetes, glucose homeostasis traits and gene expression in US participants of European and African descent. Diabetologia $2007 \quad 50 \quad$ 1621-1630. (doi:10.1007/ s00125-007-0717-x)

52 Prestwich TC \& Macdougald OA. Wnt/ $\beta$-catenin signaling in adipogenesis and metabolism. Current Opinion in Cell Biology 2007 19 612-617. (doi:10.1016/j.ceb.2007.09.014)

53 Ross SE, Hemati N, Longo KA, Bennett CN, Lucas PC, Erickson RL \& MacDougald OA. Inhibition of adipogenesis by Wnt signaling. Science 2000289 950-953. (doi:10.1126/science.289.5481.950)
54 Weedon MN. The importance of TCF7L2. Diabetic Medicine 2007 24 1062-1066. (doi:10.1111/j.1464-5491.2007.02258.x)

55 Smith U. TCF7L2 and type 2 diabetes - we WNT to know. Diabetologia 200750 5-7. (doi:10.1007/s00125-006-0521-z)

56 Yi F, Brubaker PL \& Jin T. TCF-4 mediates cell type-specific regulation of proglucagon gene expression by $\beta$-catenin and glycogen synthase kinase-3 $\beta$. Journal of Biological Chemistry 2005 280 1457-1464. (doi:10.1074/jbc.M411487200)

Received 2 February 2013

Revised version received 26 July 2013

Accepted 9 August 2013 